\title{
THE EFFECT OF MULTICOMPONENT MINERAL FERTILIZERS ON THE CONTENT OF MACRONUTRIENTS IN SOIL AFTER SUGAR BEET CULTIVATION
}

\section{WPŁYW WIELOSKŁADNIKOWYCH NAWOZÓW MINERALNYCH NA ZAWARTOŚĆ MAKROSKŁADNIKÓW W GLEBIE PO UPRAWIE BURAKA CUKROWEGO}

\author{
Department of Agronomy, West Pomeranian University of Technology, Szczecin, Poland \\ ${ }^{1}$ Grupa Azoty Zakłady Chemiczne „Police” S.A., Poland \\ ${ }^{2}$ Department of Chemistry, Microbiology and Environmental Biotechnology, West Pomeranian \\ University of Technology, Szczecin, Poland
}

\begin{abstract}
Streszczenie. Szeroka gama nawozów wieloskładnikowych, często o podobnym składzie chemicznym, różni się jakością i przyswajalnością składników pokarmowych oraz ceną. W pracy porównywano wpływ wieloskładnikowych nawozów mineralnych od polskich i zagranicznych producentów na zmiany zawartości makroskładników w glebie podczas uprawy buraka cukrowego. W przeprowadzonych badaniach analizowano również wpływ zróżnicowania dawek zastosowanych nawozów. Zastosowano nawozy wieloskładnikowe produkcji białoruskiej, rosyjskiej i polskiej. Nawóz polski to Polifoska 6 . Rośliną doświadczalną był burak cukrowy odmiany NATURA KWS, typ normalno-cukrowy. Gleba, na której realizowano doświadczenie, charakteryzowała się niską zasobnością w przypadku przyswajalnego potasu oraz średnią zasobnością w przypadku fosforu przyswajalnego i magnezu wymiennego. Doświadczenie zrealizowano w latach 2014-2017 w miejscowości Lipnik. W badaniach porównywano dwa czynniki: czynnik I. - 4 nawozy mineralne wieloskładnikowe (dwa białoruskie, jeden rosyjski i jeden polski - Polifoska 6), czynnik II. - 3 dawki nawożenia (minimalna, optymalna, maksymalna), które wynosiły odpowiednio 2,5, 5,0 i 7,5 dt/ha. Nawożenie badanymi nawozami wieloskładnikowymi nie miało wpływu na zmiany odczynu gleby $\mathrm{z}$ doświadczenia. W doświadczeniu nie stwierdzono różnicy w działaniu badanych nawozów wieloskładnikowych, produkcji białoruskiej (dwa nawozy), rosyjskiej i polskiej, w zakresie zmian zawartości w glebie przyswajalnego fosforu i potasu oraz wymiennego magnezu. Zastosowanie zróżnicowanych dawek nawozów wieloskładnikowych spowodowało istotne zwiększenie zawartości przyswajalnego potasu i wymiennego magnezu w glebie, a także przyswajalnego fosforu po zastosowaniu najwyższej dawki nawozu.
\end{abstract}

Key words: soil, available phosphorus, available potassium, exchangeable magnesium, multicomponent mineral fertilizers.

Słowa kluczowe: gleba, fosfor przyswajalny potas przyswajalny, magnez wymienny, nawozy wieloskładnikowe.

Corresponding author - Adres do korespondencji: Marzena Gibczyńska, Department of Chemistry, Microbiology and Environmental Biotechnology, West Pomeranian University of Technology, Szczecin, Juliusza Słowackiego 17, 71-434 Szczecin, Poland, e-mail: marzena.gibczynska@zut.edu.pl 


\section{INTRODUCTION}

Multicomponent mineral fertilizers are also referred to as mixed fertilizers. They contain, in various proportions, nutrients for plants such as: nitrogen, phosphorus and potassium, and other macronutrients and microelements. Multicomponent fertilizers usually have better physical properties than monocomponent ones, which facilitates their storage and sowing, as well as guarantees plants an even and optimal nutrient uptake. Availability of elements present in the soil for plants depends on many factors and is the subject of a number of studies (Rutkowska et al. 2002; Brzeziński and Sosulski 2009; Mazur and Mazur 2015; Sing and Ryan 2015). They also affect fertility rates of fertilized soils in various ways. When using multicomponent fertilizers, the fertilizer best suited to the nutritional needs of plants and the existing soil conditions should be selected from the entire range of available products. A wide range of multicomponent fertilizers, often with similar chemical composition, differs in the quality and digestibility of nutrients and price. Differences in prices between Polish fertilizers and those imported from behind the Eastern border are relatively high.

The paper compared the effect of mineral multicomponent fertilizers from Polish and foreign producers on changes in the content of macronutrients in soil during sugar beet cultivation. The study also analyzed the effect of varying doses of fertilizers used.

\section{MATERIAL AND METHODS}

\section{Experimental characteristics}

The experiment was carried out in $2014-2017$ in Lipnik $\left(53^{\circ} 41^{\prime} \mathrm{N}, 1^{\circ} 97^{\prime} \mathrm{S}\right)$, in the Agricultural Experimental Station belonging to the West Pomeranian University of Technology in Szczecin. The soil belongs to loamy sand, the IVa bonitation class (DzU 2012, poz. 1246). Soil was characterized by the following parameters: $\mathrm{pH}_{\mathrm{KCl}} 5.1, \mathrm{P}_{\text {avail }}=58.5, \mathrm{~K}_{\mathrm{avail}}=100.9$, $\mathrm{Mg}_{\text {exchan }}=64.4 \mathrm{mg} \cdot \mathrm{kg}^{-1}$.

The experimental plant was sugar beet of NATURA KWS cv., normal-sugar type. The plot area was $15 \mathrm{~m}^{2}$. The experiment was established using random blocks in 4 replications.

The study compared two factors: 1st factor -4 multicomponent mineral fertilizers: two Belarusian, one Russian and one Polish - Polifoska 6. Fertilizers used were characterized by the following composition of NPK(S): Belarusian (both A and B) 8-20-30, Russian 7-8, 19-20, 29-30 and Polish 6-20-30(7); 2nd factor - 3 doses of fertilization (minimum, optimum, maximum, which amounted to $2.5,5.0$ and $7.5 \mathrm{dt}$ per hectare, respectively). Diversification of fertilization levels - minimum, optimum and maximum - was calculated based on soil fertility in relation to phosphorus. The minimum dose was $50 \%$ less than the optimal one of $1.0 \mathrm{dt} \mathrm{P}_{2} \mathrm{O}_{5}$ per hectare, and the maximum dose was $50 \%$ higher.

Polifoska is a multi-component NPK (S) 6-20-30(7) granulated fertilizer in the form of light grey to dark grey or pink, even granules. The producer of the fertilizer is Zakłady Chemiczne "POLICE" S.A.- Police. This fertilizer is recommended for all crops: winter and spring crops, industrial, fodder and root crops. POLIFOSKA $® 6$ is recommended for use on soils that are low in potassium, in conditions of low organic fertilization and for potassophilic plants such as: sugar beet, potato, corn and rapeseed. 
In subsequent years (2015, 2016 and 2017), the following agrotechnical operations were carried out during the cultivation of sugar beet. In autumn, each year after harvest of the forecrop plant, i.e. oats, the stubble tillage was carried out applying stubble cultivator, repeating this activity twice more. In the middle of November, winter plowing was carried out with a rotary plow and in the early spring - harrowing. One week before sowing, after manual application of fertilization, the soil was prepared to a depth of about $10 \mathrm{~cm}$ by a cultivator with a string roller. Sowing was carried out with a Maschio-Gaspardo precision sowing machine maintaining a row spacing of $45 \mathrm{~cm}$ and a distance of $17 \mathrm{~cm}$ in a row. Herbicide spraying was performed after sugar beet emergence (Saherb $180 \mathrm{SC}$ at the dose of $1.0 \mathrm{dm}^{3} \cdot \mathrm{ha}^{-1}$ and Fusilade Forte 150 EC $1.0 \mathrm{dm}^{3} \cdot \mathrm{ha}^{-1}$ ). The insecticide (Sherpa $100 \mathrm{EC} 0.3 \mathrm{dm}^{3} \cdot \mathrm{ha}^{-1}$ ) was applied twice. Beets were harvested at the end of October.

\section{Methodology of chemical analyzes}

The soil $\mathrm{pH}$ was determined potentiometrically in accordance with the standard (ISO 10390/1997). Available forms of phosphorus and potassium in the soil were determined using the Egner-Riehm method (Egner et al. 1960). In order to determine exchangeable forms of magnesium content in the soil, a buffered barium chloride solution was used $(\mathrm{pH} 8.1)$ (ISO 13536:2002P). In the obtained extract, magnesium analyses were carried out applying Atomic Absorption Spectrometer Apparatus (Thermo Fisher Scientific iCE 3000 Series).

\section{Statistical analysis}

The results were statistically processed using the variance analysis in a 2-factor system of random blocks. Confidence sub-intervals were calculated using Tukey's multiple test, assuming a significance level of $p=0.05$. In addition, the analysis of variance with regression for the main effect of quantitative factor - the dose of fertilizer - was performed for selected soil features. The significance of regression equations was determined using the F-Fisher-Snedecor test. Regression lines are shown on figures. Statistical analysis of results was carried out using the Statistica 10.0 software (Mickey et al. 2004).

\section{Climatic conditions}

The average annual temperature anomaly in 2015 calculated in relation to the multi-year period $1961-1990$ reached $+2.12^{\circ} \mathrm{C}$. January 2015 was characterized by high positive anomalies. February and March were already a bit cooler. From April to June, temperatures were rather close to the thermal standard. Heat waves have started to appear in Poland since July, and July itself was very warm. The summer heat wave culminated in August. They finally ended at the beginning of September. October was even a cool month, and relatively high temperature of air maintained in November 2015 created favorable conditions for the growth and development of winter cultivars. December 2015 turned out to be the hottest December in the history of instrumental measurements. The year 2015 was extremely dry. Extreme temperatures in the summer, combined with high insolation caused that the sum of evaporation increased significantly.

The weather course in February 2016 posed a slight threat to plants, and the high temperature of air and soil that persisted during the month caused disturbances in the winter 
dormancy of plants. Weather in March favored the drying up of fields and heating the soil, as well as vegetation. Cold rainy days occurring in April inhibited the growth and development of plants. The shortage of rainfall caused that the water needs of crops were not fully satisfied. Warm and sunny weather at the beginning of May favored the growth and development of plants. As a result of the spring shortage of rainfall, condition of many crops has deteriorated. Rainfall recorded in June improved the condition of soil moisture.

The average air temperature in 2017 was $8.9^{\circ} \mathrm{C}$ and was slightly higher by $0.2^{\circ} \mathrm{C}$ than the average for the multi-year period of $8.7^{\circ} \mathrm{C}$. The warmest month turned out to be August, while the coldest month was January. In 2017 in April, cold days with rainfall significantly slowed down the rate of growth and development of plants. In the second half of June, heavy rainfall caused excessive waterlogging of the soil. September was unusually torrential month. A huge amount of water caused a strong waterlogging of soil, which hindered the harvest of root plants (http://old.imgw.pl/).

\section{RESULTS AND DISCUSSION}

\section{Soil acidity}

Soil of the control object was characterized by $\mathrm{pH}_{\mathrm{H} 2 \mathrm{O}}=5.9$ and $\mathrm{pH}_{\mathrm{KCl}}=5.1$, which according to obligatory criteria (ISO 10390/1997) makes it acidic. As a result of the use of multicomponent fertilizers, some soil acidification was recorded, but the differences were not significant (Table 1, 2).

Tabela 1. Comparison of the effect of fertilizers on changes in the $\mathrm{pH}$ value and the content of available phosphorus and potassium and exchangeable magnesium in soil (average from 2015-2017 years) Table 1. Porównanie działania nawozów na zmiany wartości $\mathrm{pH}$, zawartości fosforu i potasu przyswajalnego oraz magnezu wymiennego w glebie (średnie z lat 2015-2017)

\begin{tabular}{|c|c|c|c|c|c|c|}
\hline \multirow{2}{*}{$\begin{array}{l}\text { Parameters } \\
\text { Parametry }\end{array}$} & \multirow{2}{*}{$\begin{array}{l}\text { Control } \\
\text { Kontrola }\end{array}$} & \multicolumn{4}{|c|}{ Fertilizers - Nawozy } & \multirow{2}{*}{$\begin{array}{l}\operatorname{LSD}_{0,05} \\
\mathrm{NIR}_{0,05}\end{array}$} \\
\hline & & $\begin{array}{l}\text { Belarusian } \\
\text { Białoruś }\end{array}$ & $\begin{array}{l}\text { Russian } \\
\text { Rosja }\end{array}$ & $\begin{array}{l}\text { Belarusian } \\
\text { Białoruś }\end{array}$ & Polifoska 6 & \\
\hline $\mathrm{pH}$ in $\mathrm{H}_{2} \mathrm{O} / \mathrm{pH}$ w $\mathrm{H}_{2} \mathrm{O}$ & 5.9 & 5.7 & 5.6 & 5.8 & 5.7 & n.s. \\
\hline $\mathrm{pH}$ in $\mathrm{KCl} / \mathrm{pH}$ w KCl & 5.1 & 4.7 & 4.6 & 4.7 & 4.8 & \\
\hline \multicolumn{7}{|c|}{$\mathrm{mg} \cdot \mathrm{kg}^{-1}$} \\
\hline $\begin{array}{l}\text { Available phosphorus/ } P_{\text {avail }} \\
\text { Fosfor przyswajalny/ P przysw }\end{array}$ & 53.5 & 57.5 & 61.4 & 59.5 & 58.6 & 6.12 \\
\hline $\begin{array}{l}\text { Available potassium/ Kavail } \\
\text { Potas przyswajalny/ } K_{\text {przysw }}\end{array}$ & 84.9 & 142.1 & 147.2 & 140.9 & 140.0 & 18.73 \\
\hline $\begin{array}{l}\text { Exchangeable magnesium/ } \mathrm{Mg}_{\text {exchan }} \\
\text { Magnez wymienny/ } \mathrm{Mg}_{w y m}\end{array}$ & 58.4 & 65.0 & 66.0 & 70.0 & 66.5 & 6.63 \\
\hline Sum - Suma & 196.8 & 264.6 & 274.6 & 270.4 & 265.1 & - \\
\hline
\end{tabular}

n.s. - not significant difference - różnica nieistotna. 
Table 2. Comparison of the effect of fertilizer doses on changes in the $\mathrm{pH}$ value and the content of available phosphorus and potassium and exchangeable magnesium in soil (average from 2015-2017 years) Tabela 2. Porównanie działania dawek nawozów na zmiany wartości $\mathrm{pH}$, zawartości fosforu i potasu przyswajalnego oraz magnezu wymiennego w glebie (średnie z lat 2015-2017)

\begin{tabular}{|c|c|c|c|c|c|}
\hline \multirow{2}{*}{$\begin{array}{l}\text { Parameters } \\
\text { Parametry }\end{array}$} & \multicolumn{4}{|c|}{ Dose - Dawki [dt $\cdot$ ha $\left.^{-1}\right]$} & \multirow{2}{*}{$\begin{array}{l}\mathrm{LSD}_{0.05} \\
\mathrm{NIR}_{0,05}\end{array}$} \\
\hline & 0 & 2.5 & 5.0 & 7.5 & \\
\hline $\mathrm{pH}$ in $\mathrm{H}_{2} \mathrm{O} / \mathrm{pH}$ w $\mathrm{H}_{2} \mathrm{O}$ & 5.9 & 5.8 & 5.7 & 5.6 & n.s. \\
\hline $\mathrm{pH}$ in $\mathrm{KCl} / \mathrm{pH} w \mathrm{KCl}$ & 5.1 & 5.2 & 5.0 & 5.0 & \\
\hline \multicolumn{6}{|c|}{$\mathrm{mg} \cdot \mathrm{kg}^{-1}$} \\
\hline $\begin{array}{l}\text { Available phosphorus/ } P_{\text {avail }} \\
\text { Fosfor przyswajalny/ } P_{\text {przysw }}\end{array}$ & 53.5 & 55.6 & 57.0 & 65.2 & 8.18 \\
\hline $\begin{array}{l}\text { Available potassium/ Kavail } \\
\text { Potas przyswajalny/ Krzysw }\end{array}$ & 84.9 & 112.4 & 144.9 & 170.3 & 10.9 \\
\hline $\begin{array}{l}\text { Exchangeable magnesium/ Mgexchan } \\
\text { Magnez wymienny/ Mgwym }\end{array}$ & 58.4 & 65.9 & 66.0 & 70.3 & 7.31 \\
\hline Sum - Suma & 196.8 & 233.9 & 267.9 & 305.8 & \\
\hline
\end{tabular}

n.s. - not significant difference - różnica nieistotna.

\section{Available phosphorus and available potassium}

The amount of available phosphorus in the soil from the control object after the end of experiment was $53.5 \mathrm{mg} \mathrm{P} \cdot \mathrm{kg}^{-1}$ and it was a medium-rich soil (Table 1). In general, the action of multicomponent fertilizers tested increased the content of available phosphorus in the soil, but it was still the soil with average abundance (PN-R-04023: 1996). There was no difference in the impact depending on the application of one of four fertilizers; these contain the same amount of $20 \% \mathrm{P}_{2} \mathrm{O}_{5}$ in their composition.

Diversification of multicomponent fertilizer doses was reflected in significant increase in the amount of phosphorus available for plants to the level of $65.2 \mathrm{mg} \mathrm{P} \cdot \mathrm{kg}^{-1}$ of the soil, which is $21.9 \%$ more compared to the abundance of non-fertilized soil (Table 2, Fig. 1).
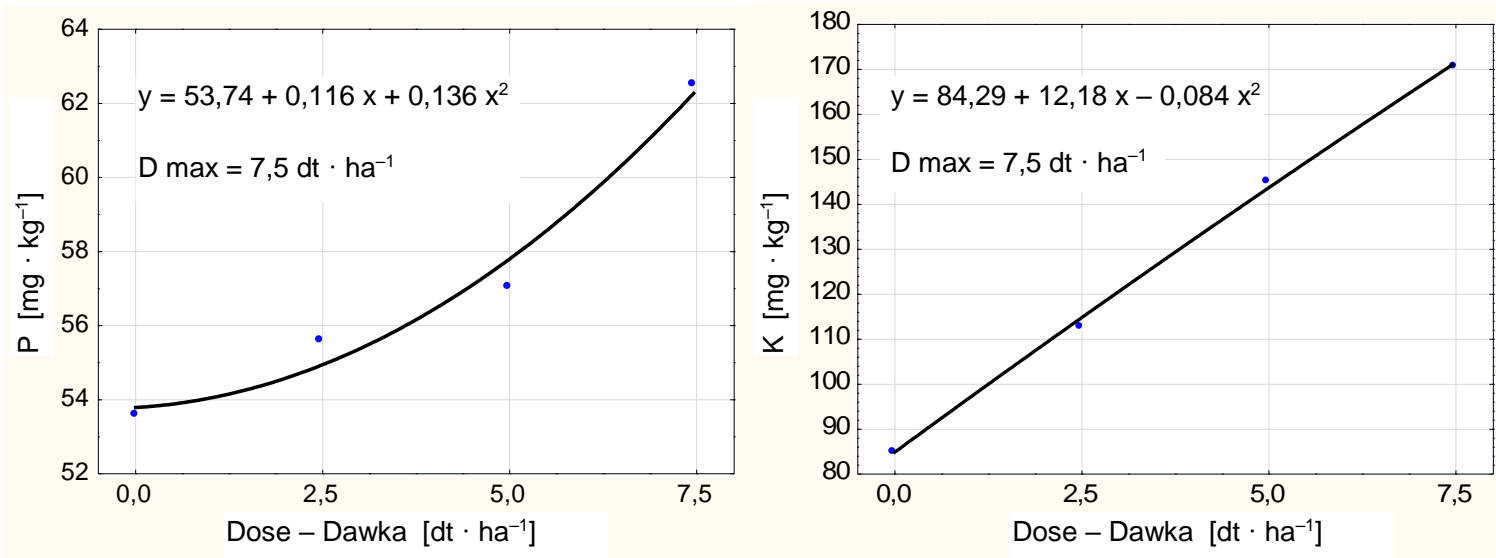

Fig. 1. Regression equation between dose of fertilizer and available phosphorus and potassium content in the soil

Ryc. 1. Równanie regresji pomiędzy dawką nawozu a zawartością przyswajalnego fosforu i potasu w glebie 
Soil from the control object contained $84.9 \mathrm{mg} \mathrm{K} \cdot \mathrm{kg}^{-1}$ and should be assessed as a soil with low potassium availability. Adding multicomponent fertilizers to the soil allowed to obtain a moderately abundant soil (PN-R-04022: $1996+$ Az1: 2002). The four fertilizers used contained in their composition the same amount of potassium, i.e. $30 \% \mathrm{~K}_{2} \mathrm{O}$, which was factor causing no differentiation of their effect on changes in the amount of available potassium in the soil (Table 1).

The amount of fertilizer dose had significant impact on the content of available potassium in the soil. Effect of the dose was proportional to the dose. Applying fertilization in the amount of $150 \mathrm{~kg} \cdot \mathrm{ha}^{-1}$, a highly-potassium-abundant soil was obtained (Table 2 and Fig. 1). Achieved results are widely documented and confirmed in the latest literature on the effect of fertilization on changes in the amount of phosphorus and potassium in the soil (Li et al. 2009; Tujaka et al. 2011; Nogalska et al. 2012; Zhan et al. 2015; Niu and Hao 2017).

\section{Exchangeable magnesium}

As a result of introducing multicomponent fertilizers into the soil, a significant increase in the amount of exchangeable magnesium in soil was obtained, by $14 \%$ calculated for the average value (Table 1). The soil of all experimental objects was characterized by average abundance of exchangeable magnesium (ISO 13536: 2002P). used did not contain magnesium (exception - Belarusian fertilizer - A), but some acidification of the soil could be a factor increasing the solubility of magnesium compounds. Explanation of the resulting dependences may also be the information given by Nowosielski (1959) that with increasing concentrations of potassium, the magnesium uptake by plants decreases and thus the amount of magnesium in the soil decreases. Other authors, on the other hand, state that the applied multicomponent fertilizers significantly increase the content of available phosphorus and potassium in the soil, and reduce the content of available magnesium (Stępień and Mercik 2001; Rutkowska et al. 2002).

Increasing doses of tested multicomponent fertilizers was reflected in changes in the amount of exchangeable magnesium in the soil from experiment; using the maximum dose $\left(7.5 \mathrm{~kg} \cdot \mathrm{ha}^{-1}\right)$, an increase of $20.4 \%$ was obtained (Table 2, Fig. 2).

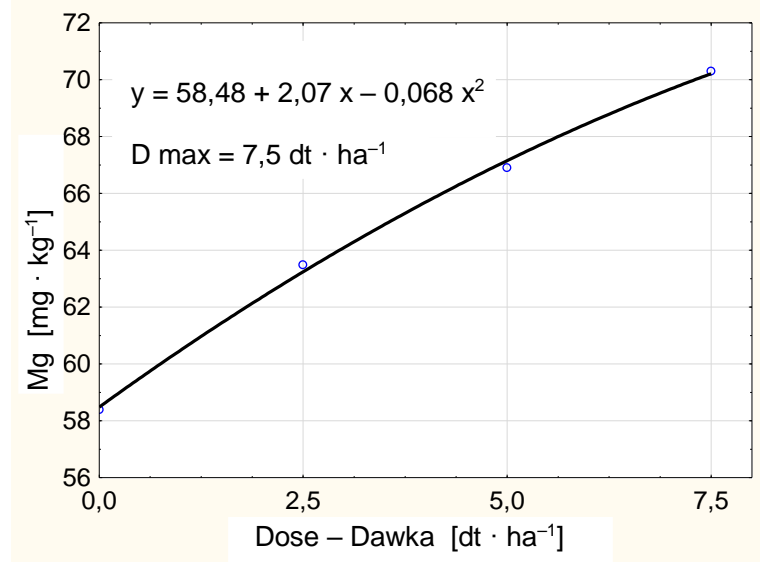

Fig. 2. Regression equation between dose of fertilizer and exchangeable magnesium content in the soil

Ryc. 2. Równanie regresji pomiędzy dawką nawozu a zawartością wymiennego magnezu w glebie 
Uniform action of the applied multicomponent fertilizers is more visible if we compare the sum of the analyzed macronutrients contents in the soil. These are values in the range from 264.6 to $274.6 \mathrm{mg} \cdot \mathrm{kg}^{-1}$, and the difference is $4 \%$.

\section{CONCLUSIONS}

1. Fertilization with multicomponent fertilizers did not have a significant impact on changes in the $\mathrm{pH}$ of experimental soil.

2. In the experiment carried out, there was no difference in the performance of tested multicomponent fertilizers: two Belarusian, one Russian and one Polish, regarding changes in the content of available phosphorus as well as available and exchangeable magnesium in the soil.

3. The use of different doses of multicomponent fertilizers resulted in a significant increase in the content of available potassium and exchangeable magnesium in the soil, and the available phosphorus after using the highest dose of fertilizer.

\section{REFERENCES}

Brzeziński M., Sosulski T. 2009. Wpływ wieloletniego nawożenia na zawartość form manganu i żelaza w glebie lekkiej [The influence of long-term fertilization on the content of mobile forms of manganese and iron in the light soil]. Zesz. Probl. Post. Nauk Rol. 541, 73-79. [in Polish]

Egner H., Riehm H., Domingo W. 1960. Untersuchungen über die chemische Bodenanalyse als Grundlage für die Beurteilung des Nährstoffzustandes der Böden. II. Chemische Extraktionsmethoden zur Phosphor - und Kalium Bestimmung. Kungliga Lantbrukshögskolans Annaler. 26, 199-215.

ISO 10390/1997P. Soil quality - Determination of $\mathrm{pH}$.

ISO 13536:2002P. Soil quality - Determination of the potential cation exchange capacity and exchangeable cations using barium chloride solution buffered at $\mathrm{pH}=8,1$.

Li F.R, Zhao W.Z., Liu J.L., Huang Z.G. 2009. Degraded vegetation and wind erosion influence soil carbon, nitrogen and phosphorus accumulation in sandy grasslands. Plant Soil. 317, 79-92.

Mazur Z., Mazur T. 2015. Influence of long-term fertilization on phosphorus, potassium, magnesium, and sulfur content in soil. Pol. J. Environ. Stud. 24(1), 185-190. DOI: 10.15244/pjoes/29203.

Mickey R.M., Dunn O.J., Clark V.A. 2004. Applied statistics: Analysis of variance and regression. New Jersey, Ed. John Wiley \& Sons, 1-448. ISBN: 978-0-471-37038-3.

Niu L.A, Hao J. 2017. Impacts of fertilizer application rates on phosphorus dynamics in salt-affected soil. Plant Soil Environ. 63(10), 468-474. DOI: 10.17221/580/2017-PSE.

Nogalska A., Sienkiewicz S., Czapla J., Skwierawska M. 2012. The effect of multi-component fertilizers on the yield and mineral composition of winter wheat and macronutrient uptake. J. Elem. 17(4), 629-628. DOI: 10.5601/jelem.2012.17.4.06.

Nowosielski O. 1959. Wpływ nawożenia na zawartość magnezu dostępnego w glebie [Effect of fertilization on the magnesium content available in soil]. Rocz. Glebozn. 8(2), 95-149. [in Polish]

PN-R-04023.1996. Agricultural chemical analysis of the soil - Determination of available phosphorus in mineral soils.

PN-R-04022:1996/Az1:2002. Agricultural chemical analysis of the soil - Determination of available potassium in mineral soils.

Rozporządzenie Rady Ministrów z dnia 12 września 2012 r. w sprawie gleboznawczej klasyfikacji gruntów. DzU z 2012 r., poz. 1246. [in Polish] 
Rutkowska B., Szulc W., Łabętowicz J., Korc M., Sałajczyk M. 2002. System nawożenia jako czynnik determinujący zasobność gleby w przyswajalne formy składników pokarmowych [The fertilization system as a factor determining soil fertility in digestible forms of nutrients]. Zesz. Probl. Post. Nauk Rol. 539, 537-543. [in Polish]

Singh B., Ryan J. 2015. Managing fertilizers to enhance soil health. 1st edition. Paris, IFA, France, Copyright IFA, 1-24.

Stępień W., Mercik S. 2001. Działanie na rośliny i glebę nawozów wieloskładnikowych i pojedynczych w zmianowaniu pięciopolowym [Effect on plants and soil of multicomponent and individual fertilizers in five-field rotation]. Folia Univ. Agric. Stein., Agricultura 223(89), 165-168. [in Polish]

Tujaka A., Gosek A., Gałązka R. 2011. Ocena przydatności metody Hedleya do oznaczania zmian zawartości frakcji fosforu w glebie [Estimation of Hedley's fractionation method applicability to the determination of changes in phosphorus fractions in soil]. Pol. J. Agron. 6, 52-57. [in Polish]

Zhan X., Zhang L., Zhou B., Zhu P., Zhang S., Xu M. 2015. Changes in olsen phosphorus concentration and its response to phosphorus balance in black soils under different long-term fertilization patterns. PLoS ONE 10(7): e0131713, http://old.imgw.pl, doi.org/10.1371/ /journal.pone.0131713, access: 10.04. 2018.

\begin{abstract}
A wide range of multicomponent fertilizers, often with similar chemical composition, differs in the quality and digestibility of nutrients and price. The paper compared the effect of mineral multicomponent fertilizers from Polish and foreign producers on changes in the content of macronutrients in soil during sugar beet cultivation. The study also analyzed the effect of varying doses of fertilizers used. Fertilizers used were characterized by the following composition of NPK(S): two Belarusian 8-20-30, Russian 7-8, 19-20, 29-30 and Polish 6-2030(7) - Polifoska 6. The experimental plant was sugar beet of NATURA KWS cv., normal-sugar type. The soil on which the experiment was carried out was characterized by low abundance of available potassium and medium available phosphorus and exchangeable magnesium. The experiment was carried out in 2014-2017 in Lipnik. The study compared two factors: 1st factor - 4 multicomponent mineral fertilizers (two Belarusian, one Russian and Polifoska). 2nd factor 3 doses of fertilization (minimum, optimum, maximum, which amounted to $2.5,5.0$ and $7.5 \mathrm{dt}$ per hectare, respectively. Fertilization with multicomponent fertilizers did not have a significant impact on changes in the $\mathrm{pH}$ of experimental soil. In the experiment carried out, there was no difference in the performance of tested multicomponent fertilizers: Belarusian, Russian and Polish, regarding changes in the content of available phosphorus as well as available and exchangeable magnesium in the soil. The use of different doses of multicomponent fertilizers resulted in a significant increase in the content of available potassium and exchangeable magnesium in the soil, and the available phosphorus after using the highest dose of fertilizer.
\end{abstract}

